\title{
INNY RODZAJ PIŚMIENNOŚCI. O ASPEKTACH NIEBINARNOŚCI ORALNOŚCI I PIŚMIENNOŚCI W LITERATURZE CHIŃSKIEJ NA WYBRANYCH PRZYKŁADACH
}

\author{
A DIFFERENT KIND OF LITERACY: \\ ON THE NON-BINARY ASPECTS OF ORALITY \\ AND LITERACY IN CHINESE LITERATURE \\ ILLUSTRATED BY SELECTED EXAMPLES
}

\begin{abstract}
A b stract. The main aim of this article is to demonstrate that the dichotomous model of orality and literacy, as proposed, for example, by Walter Ong, as well as other, more culturally "flexible", tools, such as Ruth Finnegan's definitions of these terms, are not applicable or else applicable only partially. Due to the growing doubts as to the methodological correctness of the application of these tools as adopted in the West, an attempt was made to present the essence of Chinese literacy and its very complicated relationship with orality. Research areas for further consideration of these issues are also indicated, and exemplification for these reflections has been provided by selected works, which have not been sufficiently discussed in this context despite quite an extensive bibliography on orality and literacy in China.
\end{abstract}

Keywords: Chinese literature; orality; literacy; Walter Ong; Ruth Finnegan.

\section{WPROWADZENIE}

W niniejszym artykule podjęto temat, który był podnoszony w różnym zakresie przez innych badaczy.

Oralność kultury i literatury chińskiej (i każdej innej) oraz wzajemne oddziaływanie z piśmiennością nie ulega wątpliwości. Podstawowym celem tego tekstu jest udzielenie, na podstawie przykładów pochodzących z róż-

Dr EwA PAŚNIK-TuŁOWIECKA - Uniwersytet Warszawski, Wydział Orientalistyczny, Zakład Sinologii; adres do korespondencji - e-mail: ewa.pasnik@uw.edu.pl, ORCID: https://orcid.org /0000-0003-0679-350X. 
nych epok, ale powstałych raczej w kluczowych momentach rozwoju piśmienności w Chinach (dotyczy to pierwszych znanych zapisów, zastygnięcia języka klasycznego, powrótu w literaturze do języka mówionego [vernacular]), odpowiedzi na pytanie, czy potrzebne jest rozróżnienie na oralność i piśmienność w literaturze chińskiej, biorąc pod uwagę, jak przebiegał proces wzajemnego oddziaływania na siebie pisanego i niepisanego sposobu przechowywania i przekazywania tekstów kultury chińskiej.

W pierwszej części artykułu zostanie przeprowadzona krytyka metod badawczych zaproponowanych przez badaczy zajmujących się zagadnieniami oralności i piśmienności, a następnie zostanie przedstawione nowe spojrzenie na omawiane kwestie, które uwzględnia odejście od binarnego modelu oralnośćpiśmienność i proponujące inną, bardziej emiczną definicję piśmienności. Omawiając literaturę chińską, zastosowano podział na literaturę pisaną klasycznym językiem chińskim i pisaną językiem danej epoki. Nie jest to podział idealny, ponieważ wyodrębnienie się tych dwóch kategorii jest wynikiem pewnego procesu, z którego trzeba wyciągnąć swego rodzaju średnią, żeby przyjąć statyczny termin. Jest on przy tym niezbędny, ponieważ to właśnie oficjalny powrót do pisania językiem, którym się mówi, wprowadził chińską literaturę na drogę ku „zachodniej nowoczesności” i dopiero na tym etapie zachodnie metody badawcze stają się skuteczniejsze czy wnoszące cokolwiek badawczo.

Uwzględniono również wybrane aspekty o niezwykle istotnej dla podejmowanych w niniejszym tekście rozważań kwestii oralności i piśmienności $\mathrm{w}$ literaturze ludowej, ponadto poruszane $\mathrm{w}$ artykule zagadnienia, choć są związane z piśmiennością, zdecydowano się odnieść jedynie do problemów dotyczących literatury czy piśmiennictwa chińskiego, pomijając kwestie czysto lingwistyczne, czyli dotyczące języka chińskiego, gramatyki i specyfiki znaków chińskich i wynikających z tego konsekwencji dla języka chińskiego.

\section{POJĘCIA DEFINICYJNE}

Przedstawienie podstawowych podejść do zagadnienia piśmienności i oralności wymagają zestawienia ich na postawie rozważań Ruth Finnegan oraz Waltera Onga zebranych w książce Oralność i piśmienność. Słowo poddane technologii ${ }^{1}$. Pod uwagę również zostały wzięte propozycje Alberta B. Lorda oraz Jacka Goody'ego.

\footnotetext{
${ }^{1}$ Tytuł oryginalny: Orality and literacy: The Technologizing of the Word Translated (1982). Wersja polska w przekładzie i pod redakcją naukową Józefa Japoli ukazała się najpierw w Redakcji Wydawnictw KUL w 1992 r., powtórnie w Wydawnictwach Uniwersytetu Warszawskiego w 2011 r.
} 
Rozważania nad oralnością i piśmiennością, próba uchwycenia momentu w dziejach danej kultury, w którym słowo mówione zostaje zapisane, od wielu lat zajmują badaczy wielu dyscyplin: literaturoznawstwa, językoznawstwa, kulturoznawstwa czy antropologii.

Przez niemal wiek badań zostało wysuniętych wiele definicji oralności i piśmienności, jak i kategorii (tradycja oralna, literatura oralna, ludowa, popularna, sztuka widowisk, sztuka słowa) z nimi powiązanych oraz metodologii je badających (Finnegan, Oral Traditions 5-16, 26-49). W tym niekoniecznie przeciwstawnym zestawieniu oralność-piśmienność ta pierwsza wydaje się dużo bardziej kontrowersyjna i wymyka się sztywnym definicjom, gdyż - jak pisze Ruth Finnegan, zgadzając się ze stanowiskiem Jacka Goody'ego (4-5) - że w większości przypadków nie mamy dostępu do przykładów, które pochodziłyby z „czysto oralnego” źródła, kultury całkowicie nieskażonej piśmiennością. Jeśli istnieją jeszcze kultury, w których występuje jedynie przekaz ustny, to funkcjonowały czy funkcjonują one od przynajmniej kilkuset lat na obrzeżach kultur piśmiennych i niemożliwe jest, aby nie uległy ich wpływom - i odwrotnie (Finnegan, How Oral 53-54).

Czym zatem będą charakteryzowały się gatunki, które Finnegan zaliczyła do oralnych, wyróżniając trzy, ewentualnie cztery kryteria, tj. rodzaj kompozycji, sposób przekazu, urzeczywistnienie w wykonaniu (actualization in performance) i ewentualnie źródła, $\mathrm{z}$ których dane teksty pochodzą (Finnegan, How Oral 60). Szczególny nacisk badaczka kładzie na ów aspekt wykonania i w przeciwieństwie do Alberta B. Lorda, który przestawia sytuację, gdzie komponowanie jest elementem wykonania (Lord 17), Finnegan oddziela te dwa aspekty od siebie i zauważa, że w przypadku wykonywania utworów o charakterze oralnym należy zwrócić uwagę również na publiczność oraz okazję, przy której wykonanie ma miejsce (Finnegan, Oral Literature in Africa 14). Kryteria Finnegan są dość ogólne, lecz z jednej strony dzięki temu nie tylko stosowalne międzykulturowo (sama badaczka zajmowała się przecież literaturą oralną Afryki) bez nadmiernego narzucania obcego sposobu myślenia, ale także pozwalające uwzględnić takie utwory, które zostały napisane lub czerpią ze źródeł pisanych, ale do wykonania ustnego, z drugiej zaś skutecznie spełniają swoją funkcję.

Co szczególnie interesujące, badaczka zauważa także, że „oralne” to nie tylko przeciwieństwo do „piśmienne” czy „pisane”, ale także ogólnie werbalne, co z kolei pozwala jeszcze bardziej rozszerzyć tę definicję, włączając w nią gesty, mimikę, ale i na przykład rzeźby, freski, obrazy oraz wszelkie okoliczności wykonania utworu (Finnegan, Oral Traditions 5). 
Ponieważ podejmowanym zagadnieniem jest nie tylko kwestia piśmienności, ale i literatury, warto przyjrzeć się jeszcze definicji jeszcze jednego pojęcia, a mianowicie „literatura oralna”, które jest w zasadzie oksymoronem. Finnegan zauważa wprawdzie, że biorąc pod uwagę etymologię terminu literatura (litera jest wszakże elementem zapisu) dodanie do tego przydawki „oralna” jest jego zaprzeczeniem. Zastanawia się także nad ewentualnym innymi terminami, a nawet neologizmami jak na przykład „oratura” (Finnegan, Oral Traditions 8-15), ale ostatecznie uznaje, że ze względu na fakt, że słowo „literatura” może mieć zupełnie inne znaczenie $\mathrm{w}$ innych kulturach, a także na funkcję utworów o charakterze oralnym można pozostać przy pojęciu „literatura oralna” (Finnegan, Oral Literature 18, 26).

Z tym stanowiskiem nie zgadza się Walter J. Ong, który twierdzi, że jest to „termin niedorzeczny” (Ong 41), proponując określenie „oralność pierwotna i wtórna", które zakładają istnienie kultur i w związku z tym źródeł całkowicie wolnych od jakichkolwiek wpływów piśmienności (Ong 41). Tutaj znów Ong staje w opozycji do rozważań Finnegan, wyróżniając cechy charakteryzujące „myśl oralną” (Ong 76-103).

Choć definicje Finnegan są zdecydowanie bardziej elastyczne niż dychotomiczny podział Onga, to i one nasuwają pewne wątpliwości. Przede wszystkim rodzi się pytanie: po co w ogóle rozróżniać oralność i piśmienność, skoro zakresy tych definicji mieszają się ze sobą, a więc czy wystąpienie chińskiego opowiadacza można zaliczyć do tradycji oralnej tylko dlatego, że wykonanie jest ustne, w kontakcie z publicznością, ale zarówno źródła tekstu (np. kroniki historyczne), jak i sposób jego przechowywania (notatki opowiadaczy) są całkowicie piśmienne?

Nie można nie zgodzić się z Galenem Brokawem, który w tekście An Integrational Approach to Colonial Semiosis pisze, że wprawdzie wspomniana wcześniej dychotomia nie zawsze jest nieuzasadniona, ale ma wartość głównie heurystyczną, a nie wnoszącą coś badawczo (Brokaw 106).

Komplikowanie zagadnienia, zastanawianie się, czy literatura może być oralna i czy formy oralne spełniają funkcję literatury w piśmiennej kulturze Zachodu, nie stanowi przedmiotu tego artykułu, tym bardziej że przetłumaczenie chińskiego słowa 文學 wenxue jako literatura samo w sobie jest już dość problematyczne. Na przykład książkę prezentującą wczesne teksty zaliczane do wenxue Zbigniew Słupski zatytułował Wczesne piśmiennictwo chińskie. W chińskim słowie kluczowe jest ustalenie znaczenia pierwszego znaku 文 wen. O pierwotnym znaczeniu tego znaku nie wiadomo zbyt wiele (zob. także Estetyka chińska. Antologia 17). Jak opisuje James Liu w Chinese 
Theories of Literature, znak ten pojawia się z pewnością już na kościach wróżebnych z czasów dynastii Shang (ok. 1600 - ok. 1046 p.n.e.) jako jedno z określeń zmarłego króla, ale nie ma pewności, w jakim znaczeniu. Późniejsze użycia znaku sugerują znaczenie wzoru w kratkę (przecinających się linii), a potem wzoru $w$ ogóle. Równolegle rozwijało się także inne znaczenie tego znaku: „kultura”, „cywilizacja”, „doskonalenie się”, „kształcenie”, a czasem po prostu ,tekst”. Dopiero na początku dynastii Han (206 p.n.e. -220 n.e.) zyskało znaczenie bliskie temu, jakie ma w złożeniu wenxue. Oznaczało wtedy teksty o ozdobnej dopracowanej formie, często zawierające paralelizmy i rymy, których miały za zadanie dostarczać doznań estetycznych, a nie pełnić funkcje praktyczne. Wtedy też zaczyna występować razem z xue. Późniejsze zmiany w znaczeniu miały, według Liu, wynikać z pojawienia się w użyciu słowa 筆 $b i$, „pędzel” w znaczeniu tekstu pisanego prozą, podczas gdy wen określało teksty rymowane, ale to rozróżnienie szybko zanikło. Za czasów dynastii Tang (618-907) z kolei było używane do określenia prozy $\mathrm{w}$ odróżnieniu od 詩 shi poezji, pieśni, ale funkcjonowało równolegle znaczenie obejmujące teksty pisane zarówno wierszem, jak i prozą (Liu 7-9).

$\mathrm{Z}$ tej krótkiej historii, którą przedstawia Liu, wynika, że wen ma charakter polisemiczny i może wyrażać zarówno ozdobę czy ozdobne wykończenie, wzór, jak $\mathrm{i}$ - w niektórych użyciach - zbliżone jest do tego, co nazwalibyśmy literaturą piękną. Jak jednak można przeczytać w opracowaniach dotyczących chińskiej literatury i co znajduje swoje potwierdzenie w zawartości cesarskich antologii opracowywanych do kronik dynastycznych, teksty, które nie miały funkcji dydaktycznej i służyły jednie rozrywce, były wyłączane poza granice tego, co Chińczycy nazywali „literaturą" (Idema i Haft 9). W rezultacie jej trzon stanowiły teksty historiograficzne, filozoficzne, poezja i inne teksty należące do kanonu konfucjańskiego, takie jak Księga przemian (《易經》Yijing). Stąd też używany do określenia tekstów do końca XIX wieku termin wenxue, często przekładany jest na język polski właśnie jako piśmiennictwo, a nie literatura.

W swoich rozważaniach Liu pominął jednak dość istotną definicję wen, która pojawia się w szczególnie ważnym pod względem rozważań teoretycznoliterackich utworze Wenxin diaolong (《文心雕龍》) autorstwa Liu Xie (劉劦思, ok. 465-521). Już w pierwszych słowach Liu Xie pisze:

文之為德也，大矣，與天地并生者何哉？夫玄黃色雜，方圓體分，日月疊 璧, 以垂麗天之象; 山川煥綺, 以鋪理地之形：此蓋道之文也。(Chinese Notes, http://chinesenotes.com/wenxin/wenxin001.html) 
Zaiste wielka jest $\operatorname{moc}^{2}$ wen. Zostało zrodzone wraz z niebem i ziemią. Dlaczegóż [można tak powiedzieć]? Z czarnego (niebo) i żółtego (ziemia) biorą się wszystkie kolory, a z okrągłego (niebo) i kwadratowego (ziemia) wydzielają wszystkie kształty. Słońce i księżyc, bliźniacze nefrytowe dyski [są jak] wspaniałe kształty zawieszone na niebie. A góry i rzeki [są] pięknym wzorem ukazującym się na ziemi. To są 'wen' (znaki) 'Dao' (pierwotnej zasady). (Por. Estetyka chińska. Antologia 113)

Widać tu wyraźnie, że znakami „wytworzonymi” przez Dao są przepiękne kształty i wzory gwiazd na niebie i rzek czy gór na ziemi, a literatura będąca wytworem człowieka powinna naśladować owe wzory Dao. Kosmos nie komunikuje się zatem z człowiekiem za pomocą wypowiadanych słów, kosmos tworzy wzory, pisze. To nie dźwięk czy słowo jest sprawcze, a wen (wzór).

Do tego samego fragmentu Wenxin diaolong odwołuje się również Liangyan Ge w niezwykle ważnej książce Out of the Margins. The Rise of Chinese Vernacular Fiction. Autor przywołuje dodatkowo jeszcze dwie legendy pojawiające się w dalszych paragrafach Wenxin diaolong - o Cang Jie 倉頡, legendarnym historyku Żółtego Cesarza, który miał wynaleźć chińskie znaki, obserwując ślady ptaków na piasku³, oraz o powstaniu znajdujących się w Księdze przemian trygramów i heksagramów. Podstawowe osiem trygramów (八卦 bagua) miało wywodzić się ze wzorów na plecach mitycznych stworzeń - żółwia z rzeki Luo i „smokonia” z Żółtej Rzeki, heksagramy natomiast miały powstać w wyniku obserwacji znaków na niebie (Ge 201). Po raz kolejny widać wyraźnie, że chińskie znaki i tekst nimi zapisany jest naśladowaniem kosmicznych wzorów (Ge 12-13).

Sytuację badań na oralnością i piśmiennością w literaturze chińskiej dodatkowo komplikuje fakt, że po wprowadzeniu systemu edukacji przygotowującego do egzaminów urzędniczych, który polegał w głównej mierze na wyuczeniu się na pamięć i następnie naśladowania ich we własnej twórczości, język pisany szybko skostniał (Idema i Haft 20-22). Owe wzorcowe teksty pisane były w języku klasycznym, czyli w wenyanie, który utrwalony przez wspomniany przed chwilą system edukacji, nie ulegał naturalnym zmianom języka i w pewnym momencie przestał być językiem, którym porozumiewano się w danej epoce.

\footnotetext{
${ }^{2}$ Tutaj znak 德 de można thumaczyć jako cnotę (zob. The Literary Mind, epub, 16\%) lub jako moc (zob. Ge 12).

${ }^{3}$ Ge przywołuje tu wersję legendy z Roczników pana Lü (《呂氏春秋》[Lüshi Chunqiu]), lecz w przypisie opisuje również inne wersje (zob. Ge 201).
} 
Słowo 文言 wenyan również zostało zdefiniowane we wspomnianym już wcześniej Wenxin diaolong. Można dowiedzieć się stamtąd, że Konfucjusz, pisząc komentarz filozoficzny do Księgi przemian, czyli „Skrzydła” (翼 yi) (więcej zob. Religa 98), nazwał wenyanem swój komentarz dotyczący heksagramów „Niebo” (乾 qian) i „Ziemia” (坤 kun),

而《乾》、《坤》兩位, 獨制《文言》。言之文也, 天地之心哉 (Chinese Notes, $\mathrm{http}: / /$ chinesenotes.com/wenxin/wenxin001.html)

[Konfucjusz] jedynie do dwóch heksagramów „Qian” i „Kun” napisał „Wenyan”. Jest to ozdoba słów, istota nieba i ziemi. (Por. Estetyka chińska. Antologia 114)

Choć taki system edukacji niewątpliwie można by określić jedną z wyróżnionych przy okazji definiowania przez Onga kultur oralnych cech, a mianowicie zachowawczością czy tradycjonalizmem (Ong 81-83), to z czasem doprowadził do sytuacji, w której język pisany całkowicie skostniał i przestał być zapisem żywego języka mówionego. Tak było w dużej mierze aż do początków XX wieku. Według Idemy i Hafta rozbieżność między językiem mówionym (白話 baihua) i pisanym zwanym wenyanem (文言) zaczęła się już pojawiać w czasach panowania Zachodniej Dynastii Han (206 p.n.e. 48 n.e.), a widoczna była za Wschodnich Hanów (25-220) (Idema i Haft 7).

Rozpatrując zatem kwestie związane z oralnością i piśmiennością literatury chińskiej, należy pamiętać, że przez długi czas nawet literatura rozrywkowa i tworzona do ustnego wykonania była zapisana językiem klasycznym, wenyanem, językiem pisanym, a nie mówionym w danej epoce, a co za tym idzie - skierowana do bardzo wąskiego grona piśmiennych odbiorców. Czy zatem można mówić w takim przypadku o oralności? Z czasem szczególnie literatura rozrywkowa zaczęła powoli mówić językiem swojej epoki, co zostanie szerzej omówione w części II.2. Uświadomiwszy sobie, że teksty należące do wenxue w klasycznym rozumieniu tego słowa, pisane przez i skierowane do - jak zauważono wcześniej - bardzo nielicznej grupy wykształconych urzędników i arystokratów, to tylko kropla w morzu twórczości Chińczyków i istnieje wprost niezmierzone bogactwo form oralnych tworzonych przez niepiśmienny lud, form, które niewątpliwie wpływały na elitarną literaturę, to dopiero wtedy można dostrzec tę wielowymiarowość wzajemnego oddziaływania i przenikania się oralności i piśmienności, o której pisze Finnegan. 


\section{EMICZNA PIŚMIENNOŚĆ}

W tej części zostanie podjęta próba ukazania, czym charakteryzowała się najwcześniejsza piśmienność chińska. Najpierw zostaną omówione najstarsze teksty, a cezurą jest tu koniec dynastii Han, kiedy różnice między językiem mówionym a pisanym zaczęły już być widoczne. Nie jest to granica bardzo sztywna i czasami zostanie ona przekroczona w jedną lub drugą stronę. Mowa jest tu bowiem o pewnym procesie i trudno trzymać się konkretnych dat. Następnie zaś zostaną przedstawione wybrane przykłady z czasów, gdy język epoki zaczynał przedostawać się do skostniałość i pozostającego w powszechnym użyciu autorów wenyanu.

\section{Najstarsze Zabytki piśmiennictwa Chińskiego. STUDIUM WYBRANYCH PRZYKŁADÓW}

Inskrypcje na kościach wróżebnych (甲骨文 jiaguwen) są uważane za najstarsze zabytki piśmiennictwa chińskiego. Pochodzą one głównie z czasów dynastii Shang i są zapisem okoliczności oraz słów wypowiedzianych podczas rytuału wróżebnego. ${ }^{4}$ Większość inskrypcji oprócz daty, nazwiska wróżbity i tematu wróżby ${ }^{5}$ zawiera frazę 王占日 (wang zhan yue, „król, prognozując, powiedział”) lub 王卜曰 (wang bo yue, „król, wróżąc, powiedział") i następnie następuje zapis samej wróżby i ewentualnie, choć nie zawsze, weryfikacja, czy wróżba się spełniła, czy nie. Oznacza to, że inskrypcja na kości wróżebnej częściowo była utrwaleniem słów króla lub dużo rzadziej wróżbity przepowiadającego przyszłość. Kluczowym znakiem, któremu należy się przyjrzeć, jest znak 曰 yue, który oznacza tyle, co „mówić" i w tekstach klasycznych wprowadza mowę niezależną. Sam w sobie znak jest dość prosty do rozszyfrowania, gdyż przedstawia otwarte usta i wypływające $z$ nich słowa. Jest to zatem znak, w którym zastygł niejako akt mówienia.

Cały rytuał był zatem niczym innym jak komunikacją między królem a bóstwami lub przodkami, której wyniki ogłaszane były werbalnie. Można założyć, choć są to jedynie spekulacje, że przebieg rytuału pozwalającego nawiązać kontakt z zaświatami za pomocą jakiegoś pośrednika był silnie zrytualizowany, a więc miał charakter performatywny. K.C. Chang uważa,

\footnotetext{
${ }^{4}$ Więcej infromacji zob. Keightley 28-56 oraz Słupski 58-61.

${ }^{5}$ Badacze spierają się, czy można nazwać tę część inskrypcji pytaniem, czy też nie. Zob. Qiu $77-114$
} 


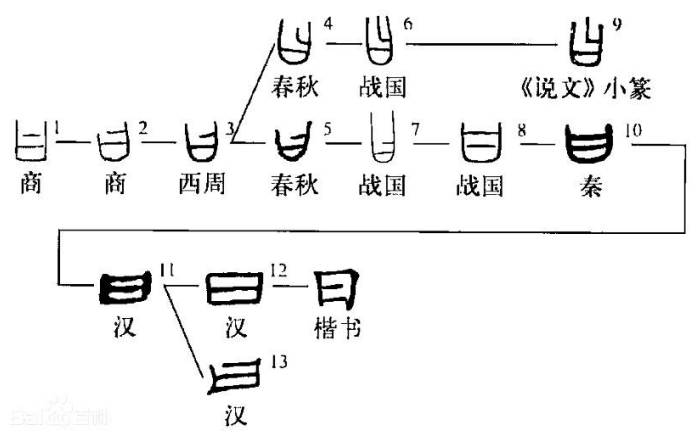

Ilustracja 1. Ewolucja znaku 曰 yue.

Źródło: baike.baidu.com/pic/\%E6\%9B\%B0/9421784/0/78310a55b319ebc4b74584119e6fd8fc1e $178 \mathrm{~b} 82 \mathrm{~b} 8 \mathrm{a} 8 \mathrm{ffr}=$ lemma\&ct=single\#aid=0\&pic=78310a55b319ebc4b74584119e6fd8fc1e178b82b8a8 , dostęp 23.03.2021.

że znak 賓 bin, który pojawiał się czasem na shangowskich kościach wróżebnych między znakiem oznaczającym króla i bóstwo/przodka, do którego się zwracał, oznaczał „wizytować”, „gościć”. Sugeruje on, według Changa, że elementem rytuału wróżebnego mogla być inkorporacja (goszczenie) bóstwa/przodka, lecz - jak sam za chwilę zauważa - użycie znaku bin wskazuje raczej, że kierunek czynności przezeń oznaczanej odbywał się w przeciwną stronę, czyli to król udawałby się z wizytą w zaświaty (Chang 54). Jest dość wątpliwe, że znak bin miał związek z szamańskim transem, co sugerował Chang. W najstarszych tekstach oznacza on również „oddawać cześć”. Jeśli przyjęlibyśmy to znaczenie, to wtedy po prostu król oddawałby cześć bóstwu/przodkowi, co także może wskazywać na sformalizowany i performatywny charakter tego rytuału i potwierdzać dodatkowo oralny aspekt wróżb shangowskich.

Innym, już mniej oczywistym przykładem niż yue znaku, który występuje w inskrypcjach na kościach wróżebnych i w którym zastygł nie tylko akt mowy, ale i czynność rytualna, jest znak 祝 zhu. Zhu współcześnie oznacza „życzyć”, „modlić się” i rzeczownikowo „kapłan”. W najstarszych formach wartość semantyczną znaku widać wyraźniej, jest to osoba klęcząca z ustami zwróconymi ku górze/niebu' ${ }^{6}$. Znak ten utrwalił zatem nie tylko modlitwę, ale również cały rytualny gest $\mathrm{w}$ postaci klęczenia. Jest zatem zapisem rytuału oralno-performatywnego, jakim jest modlitwa.

\footnotetext{
${ }^{6}$ Więcej informacji zob. 沈培, t. 2, 1-30.
} 


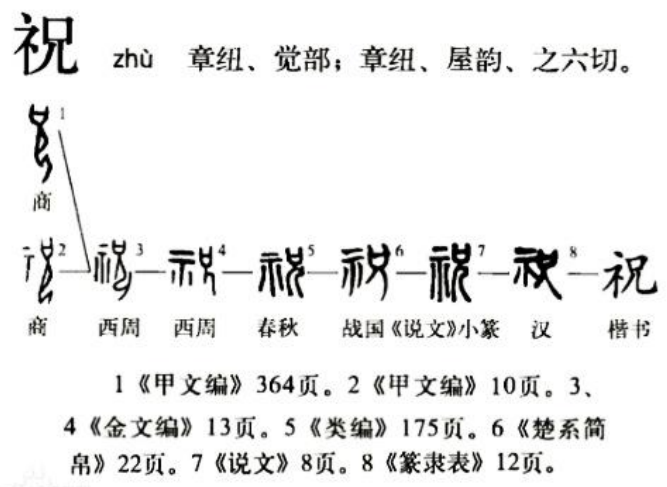

Ilustracja 2. Ewolucja znaku zhu.

Źródło: baike.baidu.com/pic/\%E7\%A5\%9D/54167/0/9a504fc2d56285355d3f24ea9cef76c6a6 ef631a?fr=lemma\&ct=single\#aid=0\&pic=9a504fc2d56285355d3f24ea9cef76c6a6ef631a, dostęp 23.03.2021

$\mathrm{Na}$ podstawie zachowanych inskrypcji nie można stwierdzić, czy rytuał wymagał od wróżbity czy innych uczestników rytuału odtwarzanie poszczególnych modlitw z pamięci. Jest to bardzo prawdopodobne, skoro nie skorzystano z możliwości odciążenia pamięci w postaci czegoś w rodzaju notatek do rytuału, jak ma to na przykład miejsce w przypadku rękopisów Naxi. Można by było się zastanawiać, czy przypadkiem takie wspomagające pamięć zapiski nie były zbyt mało ważne, by zostać zachowane, tak jak inskrypcje wróżebne. Wiadomo już jednak, że inskrypcje nie powstawały dla potomnych. Po pewnym czasie (zwykle niezbyt długim, bo przepowiednie dotyczyły raczej spraw bieżących), gdy sprawdzono prawdziwość wróżby, były po prostu wyrzucane (Słupski 61).

$\mathrm{Na}$ podstawie tych kilku przykładów można powiedzieć, że w pewnym sensie inskrypcje na kościach wróżebnych można nazwać „artefaktem kultury oralnej"7. Nie można jednak zakładać, że wszystkie znaki chińskie posiadające element ust są związane $\mathrm{z}$ aktem mowy, czyli sugerują oralny charakter danego słowa. Wiele $\mathrm{z}$ nich jest związanych na przykład z jedzeniem lub jego brakiem. Na przykład znak 吃 chi ,jeść” (zob. Gang Yue 19).

Analizując podane wcześniej chińskie definicje słowa wenxue (literatura/ piśmiennictwo) oraz inskrypcje na kościach wróżebnych, można pokusić się o postawienie hipotezy, że skoro kosmos/przodkowie/zaświaty komunikują

\footnotetext{
${ }^{7}$ Takiego stwierdzenia użył w prywatnej korespondencji Marian Olech, doktorant na National Chengchi University na Tajwanie, zajmujący się badaniem inskrypcji na kościach wróżebnych.
} 
się z człowiekiem za pomocą wen (wzorów), a w przypadku kości wróżebnych za pomocą pęknięć, które powstawały po przyłożeniu rozżarzonego końca pręcika czy drewna, to w takim razie być może interpretacja i pozostałe zapisy były również próbą nawiązania komunikacji z zaświatami. Wtedy pismo, odwzorowujące wzory występujące w naturze, i powstała z nich później literatura nie miałyby tylko walorów estetycznych, ale funkcję komunikacji właśnie z szeroko pojętymi zaświatami. A zatem może należy rozpatrywać kwestie wen i wenxue poprzez teorię komunikacji, a nie rozróżniania na piśmienność i oralność.

Nawiązując jeszcze do rytuałów, które wspomniane są w tekście, lecz bez żadnych modlitw, co może sugerować konieczność przechowywania ich w pamięci, można wspomnieć jeszcze o dość niezwykłym tekście w historii literatury/piśmiennictwa chińskiego, a mianowicie Księdze gór i mórz 《山 海經》. Jest to tekst, którego najstarsze fragmenty pochodzą z okresu Walczących Państw (戰國 zhanguo, 770-221 p.n.e.), a najmłodsze z początków dynastii Han. Księga początkowo miała składać się z samych ilustracji, przedstawiających różne dziwne rośliny, zwierzęta, krajobrazy, społeczności, zebranych czy sporządzanych $\mathrm{w}$ trakcie regularnych objazdów przez władcę swoich ziem (Birrell xiv). Ilustracje te nawet po późniejszym uzupełnieniu tekstem są charakterystycznym elementem każdego wydania Księgi gór i mórz. W najmłodszej części Księgi, czyli w pięciu pierwszych rozdziałach stanowiących Księge gór, na końcu każdej zamkniętej części związanej z kierunkiem geograficznym znajduje się podsumowanie, w którym jest wspomniane, jakie bóstwa zamieszkują dany łańcuch górski, jak wyglądają i jakie należy składać im ofiary.

凡《南次三經》之首, 自天虞之山以至南禺之山, 凡一十四山, 六千五百三十

里。其神皆龍身而人面。其祠皆一白狗祈, 精用稌。(ChineseNotes, http://chinese notes.com/ wenxin/wenxin001.html)

W trzeciej części rozdziału „Góry południowe” od góry Tianyu do góry Nanyu w sumie wszystkich [omówionych] gór jest czternaście, które rozciągają się na obszarze 6530 li. Bóstwa [je zamieszkujące] mają ciało smoka i ludzką twarz. Dla wszystkich w ofierze [należy] złożyć jednego białego psa, a jako ryżu ofiarnego [należy] użyć ryżu kleistego.

Większość opisów jest bardzo zbliżona do powyższego. Niektóre bóstwa wymagają bardziej skomplikowanych ofiar i rytuałów, do których potrzebny jest zarówno $w u$ (巫), szaman, jak i zhu (祝), kapłan. W każdym przypadku jednak opisy są niezwykle lakoniczne. Jeżeli Lu Xun (魯迅, 1881-1936) miał 
rację, pisząc, że Księga gór i mórz była książką, podręcznikiem szamanów $w u$ (古之巫书) (魯迅 7-8), to cała treść rytuału musiała być przekazywana ustnie i przechowywana w pamięci $w u$, co wskazywałoby na cechę charakterystyczną dla kultur oralnych. Wprawdzie Ong zauważa, że obecność podręczników, pomocy odciążających pamięć, by mogła zająć się nowymi rzeczami, jest charakterystyczna dla kultur, które zinterioryzowały już druk (Ong 84), ale nie znajduje to w tym przypadku potwierdzenia, jak też na przykład w przypadku rękopisów Naxi.

Poza aspektem rytualnym pozostałości oralności można doszukiwać się także w starożytnych tekstach filozoficznych. W pierwszym momencie przychodzą na myśl Analekta, które są niczym innym jak zapisem rozmów (pytań i odpowiedzi) między Konfucjuszem a jego uczniami. Z jednej strony warstwa oralna tego tekstu jest dość oczywista i zaznacza się często przez wprowadzenie mowy niezależnej przy pomocy czasownika yue (子曰, „mistrz powiedział”). W tym kontekście można jednak wspomnieć o innym tekście, który należy do tradycji taoistycznej, a mianowicie o Wewnętrznej praktyce (《內業》 Neiye). Jest to tekst, który jest jednym z rozdziałów Guanzi (《管子》) i uznawany jest za jeden z najwcześniejszych tekstów taoistycznych, najprawdopodobniej starszy niż najstarsza wersja Daodejingu (Księgi drogi i mocy), do której mamy współcześnie dostęp (Roth 23-30). Neiye napisane jest wierszem, niemalże w całości rymowane, gdzie znaczna większość wersów składa się z czterech sylab/znaków, choć można znaleźć również pojedyncze wersy pięcio- lub sześcioznakowe.

Rym i rytm bardzo często wskazują na ustny przekaz lub kompozycję do ustnego odtwarzania tekstu, co zauważa to również i Roth (14), a podobna sytuacja ma miejsce także w przypadku Daodejingu.

Jak wcześniej wspominano, według Finnegan i Lorda formuła kompozycji jest niezwykle istotnym elementem literatury/kultury oralnej, jednocześnie oprócz rymu i rytmu można zauważyć ongowską addytywność i nagromadzenie (Ong 76-78).

治心在於中，

治言出於口,

治事加於人,

然則天下治矣。

一言得而天服，

一言定而天玨,

之謂也。

(Chinese Text Project, ctext.org/guanzi/ nei-y)
Uporządkowany umysł wewnątrz,

(i) Uporządkowane słowa wychodzą z ust,

(i) Uporządkowane zadania przydzielane są innym,

Wtedy wszystko pod niebiosami będzie uporządkowane,

Jedno słowo uchwycone, a niebo jest posłuszne

Jedno słowo ustabilizowane, a niebo słucha

O tym jest tu mowa 
Powyższe tłumaczenie jest bardzo dosłowne, celowo bowiem pominięto wszelkie wygładzenia i poprawki, które aż się proszą, żeby je zrobić, by tekst był logiczny, prowadzony według rozumowania przyczynowo-skutkowego, tak charakterystycznego, według Onga, dla kultur piśmiennych (Ong 77-78). Starano się zachować jak największą dosłowność, żeby wykazać pojawiające się addytywność i powtórzenia. Warto jeszcze dodać, że niemal identyczne frazy jak wers trzeci od końca i przedostatni pojawiają się jeszcze w innych miejscach w tekście.

Michael LaFrague określa Daoejing jako uwieczniający fazę pośrednią między oralnością a piśmiennością i porównuje go pod tym względem do Biblii (196). Cały tekst zaś nazywa „kolażem powiedzeń” (sayings collages), który wywodzi się z tradycji oralnej (LaFargue ix-x).

Zhuangzi (inny taoistyczny traktat, przypisywany Zhuangowi Zhouowi 莊周, 369-298 p.n.e.) różni się oczywiście formą od omawianych powyżej dwóch tekstów. Przede wszystkim nie jest napisany wierszem, jego więc kompozycja nie wskazuje na bezpośrednie związki z oralnością. Związków tych można jednak doszukiwać się w warstwie mitologicznej traktatu, ale dużo ciekawsze wydaje się pojawiające się momentami zabarwienie agonistyczne tekstu (Ong 118), którego autor podśmiewuje się i trochę prowokuje myślicieli innych niż taoistyczna tradycji, w szczególności Konfucjusza. Cecha ta widoczna jest nieco wyraźniej $\mathrm{w}$ omawianych nieco szerzej w następnej części tekstach buddyjskich, lecz warto o niej wspomnieć również przy okazji omawiania utworów taoistycznych.

Przedstawione wyżej przykłady niekoniecznie mogą służyć jako całościowa reprezentacja starożytnych tekstów. Można jednak powiedzieć, że gdyby przyjrzeć się językowi i kompozycji przedhanowskiej literatury czy piśmiennictwa, z pewnością można by odkryć nawet nie tyle pozostałości oralności, ale jej całe pokłady. A nie wspomniano nawet jeszcze o poezji i choćby Księdze pieśni (《詩經》shjing), która zostanie wspomniana jeszcze później. Jeśli zastanowimy się nad faktem, że to właśnie te starożytne teksty, niosące w sobie ogromną spuściznę tradycji oralnej, stały się wzorem literackim na następne wieki, to już możemy zauważyć, że zupełnie inaczej kształtowała się rola oralności i piśmienności w literaturze i kulturze chińskiej, niż jak chciałby widzieć to Ong, w linii prostej od oralności do piśmienności. 


\section{ORALNOŚĆ, BAIHUA A LITERATURA PISANA WENYANEM}

Jak już wspomniano, pod koniec dynastii Han zaczęły się pojawiać różnice między językiem mówionym a klasycznym. Za czasów dynastii Tang były już dość widoczne. Jeśli chodzi o użycie języka mówionego w piśmie, nie da się przecenić roli buddyzmu, było bowiem ku temu kilka powodów.

Po pierwsze, bardzo dużo słów pochodziło z sanskrytu, co dało impuls do opracowania systemu fanqie (反切) do zapisywania dźwięków znakami (Ge 17). Ponadto buddystom nie zależało tylko na nawracaniu bardzo wąskiej grupy biegle władających wenyanem urzędników i arystokratów, ale przede wszystkim ludu, najczęściej niepiśmiennego. Stąd nacisk kładziony był na oralne metody przekazania nauk Buddy i dlatego czytano sutry i wyjaśniano ich znaczenie. Nawet w bianwenach (變文) (Mair 9-32), pisanych częściowo wierszem, częściowo prozą tekstach o tematyce buddyjskiej, a potem również świeckiej, które pojawiły się właśnie za Tangów, używano w dużej mierze języka mówionego. Ponadto należy pamiętać, że cała praktyka buddyjska jest skupiona na doświadczeniu, które nie da się ująć w słowach, jest poza nimi (co Chińczycy już przecież znali doskonale z pierwszej linijki Daodejingu: 道可道非常道 Dao, które da się powiedzieć/ująć w słowach, nie jest prawdziwym/wiecznym Dao), dlatego dodatkowe wysiłki na stylizowanie przekazu były po prostu zbędne. Gdy buddyzm zadomowił się w Chinach na tyle, że zaczęły powstawać rodzime szkoły buddyjskie, w tym Chan (禪), bardzo szybko wykształciły się nowe gatunki literackie, których cechą charakterystyczną było użycie właśnie języka danej epoki. Mowa tu głównie o yulu (語錄), które można przetłumaczyć jako zanotowane/ zapisane powiedzenia, oraz powstałych z nich gong'anach (公案), czyli koanach (Wang 26-28). Zapisywanie słów mistrzów w postaci pytań i odpowiedzi nie jest nowością w chińskim piśmiennictwie i - jak zauważa Ge - gatunek sam w sobie nie odegrał wielkiej roli w przywracaniu języka epoki literaturze, ponieważ bardzo szybko przekształcił się w gatunek poetycki (18).

Nie ma jednak wątpliwości, że yulu i koany były mocno zakorzenione w oralności. Poniżej znajduje się przykład jednego z najsłynniejszych koanów (54) z Zapisów Błękitnej Skaty (《碧嚴錄》biyanlu), który jest pełen nie tylko wypowiadanych słów, ale i gestów.

\footnotetext{
雲門問僧近離甚處。僧云。西禪。門云。西禪近日有何言句。

僧展兩手。門打一掌。僧云。某甲話在。門却展兩手。僧無語。

門便打. (NTI Reader, ntireader.org/taisho/t2003_06.html)
} 
Yunmen zapytał mnicha: „Skąd przybywasz?” Mnich powiedział: „Xichanu”. Men powiedział: „Jakich słów używa/co mówi się obecnie w Xichanie?” Mnich wyciągnął obie ręce. Men uderzył go raz. Mnich powiedział „Ja jeszcze mówię”. Men wyciągnął obie ręce. Mnich oniemiał. Men uderzył go ponownie.

Głównym zadaniem koanów było wytrącenie adepta z kolein konwencjonalnego myślenia, by zaskoczony umysł mógł osiągnąć oświecenie. W owych podchwytliwych pytaniach, na które nie oczekuje się w zasadzie odpowiedzi, w prowokowaniu do ,zapasów intelektualnych”, w aktach przemocy stosowanych przez mistrzów znów można doszukiwać się opisanego przez Onga agonistycznego zabawienia, charakterystycznego dla utworów kultur oralnych. Jak pisze Ong: „Przysłów i zagadek nie wykorzystuje się do prostego przechowywania wiedzy; mają one wciągnąć innych ludzi do zapasów intelektualnych i werbalnych (...)" (85). W ten sam sposób można interpretować opowieść o tym, jak Huineng (慧能, 638-713) został szóstym patriarchą (zob. The Platform Sutra).

Przy okazji buddyzmu należy wspomnieć także o niezmiernie ważnym przekazie ustnym, który mógł się odbyć tylko wtedy, gdy mistrz odczytywał na głos tekst czy też różnych ezoterycznych praktykach $\mathrm{z}$ dźwiękiem, jak recytowanie mantr czy wypowiadanie zaklęć, gdzie dźwięk miał mieć moc magiczną (Copp 142-172; Sørensen 41-71), co również według Onga ma wskazywać na oralny charakter danej kultury (126)

Zasygnalizowawszy rolę buddyzmu zarówno w uwspółcześnieniu języka pisanego, jak i w rozwoju nowych gatunków do wykonania ustnego, nie można nie powiedzieć o literaturze rozrywkowej, zwanej czasem popularną. Była ona związana $\mathrm{z}$ rozwojem miast $\mathrm{i}$ z jednej strony pojawieniem się mieszczaństwa, kupców, którzy, choć byli piśmienni, nie byli zainteresowani literaturą pisaną w archaicznym języku. $Z$ drugiej strony zaś miasta przyciągały ludność okolicznych wsi, która przybywała tam w celach zarobkowych i przynosiła z sobą swoje pieśni i opowieści, inspirujące twórców. Pojawili się więc nowi odbiorcy, a co za tym idzie - zapotrzebowanie na nowe gatunki literackie. Większość z nich miała charakter performatywny, a jeśli były zapisywane (klasyczna powieść chińska), to widoczna jest w nich dążność do pisania językiem epoki, baihua. Taka literatura zaczęła się już pojawiać za Tangów, ale prawdziwy rozwój przeżywała za panowania dynastii Ming (1368-1644). Jest to temat, który już został doskonale opisany. We wstępie do książki The Interplay of the Oral and the Written in Chinese Popular Literature pod redakcją Vibeke Børdahl i Margaret B. Wan redaktorki książki nie tylko przedstawiły dotychczasowy stan badań nad literaturą 
popularną, ale i zarysowały ogólnie problem relacji między oralnością i piśmiennością w chińskiej literaturze popularnej (1-2). Mottem tego zbioru monografii są słowa Ruth Finnegan o wzajemnym przenikaniu się oralności i piśmienności. Może to rodzić pytanie, czy redaktorki nie zdawały sobie sprawy z konsekwencji badawczych podziału chińskich tekstów na oralne i piśmienne, czy też z pełną świadomością użyły tych terminów, aby wskazać, że w momencie, gdy do literatury zaczął powracać mówiony język epoki, a literatura zaczęła zmieniać swoje funkcje, kategorie Finnegan są przystawalne.

Co ciekawe, performatywne formy chińskiej literatury popularnej nie mogą, według Onga, zostać określone mianem „oralnych”, ponieważ powstała w kulturze od mniej więcej tysiąclecia piśmiennej, nie wspominając już o tym, że część z nich czerpała inspiracje z klasycznej literatury chińskiej (The Interplay of the Oral and the Written 2). Podobnie sytuacja wygląda w przypadku dramatu, albowiem na podstawie definicji Ruth Finnegan nie ulega wątpliwości, że jest formą należącą do literatury oralnej, Ong jednak nie zaliczyłby jej do wytworów kultury oralnej.

Rozważania nad literaturą pisaną w baihua prowadzą do bardzo ciekawego wniosku, swoistego paradoksu. Widać bowiem wyraźnie, że coraz szersze użycie języka epoki w utworach literackich umożliwiło, z jednej strony, rozwój performatywnych form literatury (說唱文學 shuochang wenxue), które tak bujnie rozwijały się czasach dynastii Ming i Qing (16441912), udostępniło tę literaturę szerszej grupie odbiorców, z drugiej strony jednak strony ostatecznie otworzyło drzwi literaturze chińskiej do nowoczesnej piśmienności w rozumieniu zachodnim.

Dość kuszące byłoby użycie w tym miejscu ongowskiego terminu ,pozostałości oralności” na określenie tych wszystkich „oralnych aspektów” chińskiej literatury czy piśmiennictwa. Ong używa tego terminu do wykazania cech „oralności pierwotnej” w tekstach wytworzonych przez kultury już niekoniecznie „oralnie pierwotne”. Jeśli założymy, że mówimy o elementach oralności w tekstach pisanych, to sam zabieg jest tak samo akceptowalny, jak używanie terminu „literatura oralna”. Nie byłby to również pierwszy raz, gdy narzędzia Onga były stosowane do badania chińskiej kultury. Jednym z przykładów może być napisany przez Davida Ze artykuł Walter Ong's Paradigm and Chinese Literacy. Artykuł Ze, mimo że jest bardzo ogólny, to jednak niektóre spostrzeżenia w nim zawarte są bardzo inspirujące. Zauważa on bowiem, że całe klasyczne piśmiennictwo czy literatura chińska wykazują, według definicji Onga, więcej cech oralności niż piśmienności. 
Niestety chińskie egzemplifikacje poszczególnych ongowskich kategorii wydają się być przytoczone bez żadnego klucza. Nie należą do jednego gatunku czy nawet rodzaju literackiego ani epoki. Czasem nie ograniczają się nawet jedynie do literatury i nie są poddawane głębszej analizie. Podobną próbę wykazania zastygłej $\mathrm{w}$ tekście oralności w tekstach starożytnego Egiptu podjął Dániel Takács w tekście zatytułowanym Performing Eternally: Visible Signs of Oral Tradition in Ancient Egypt, który użył tej samej metody do analizy hieroglifów egipskich. Takács w przeciwieństwie do Ze zdaje się widzieć nieprzystawalność teorii Onga do zupełnie innej kultury, ale ostatecznie jej nie odrzuca, tylko próbuje potraktować ją wybiórczo, przez co argumentuje choćby częściową zasadność jej użycia. Znów jednak powraca pytanie, czy konieczne jest nieustanne rozgraniczanie tych dwóch kategorii. Może należy tak jak wspomniany wcześniej Brokaw użyć takich kategorii medium czy komunikacja zaproponowanych przez McLuhana (Brokaw 105-116).

Na podstawie powyższych rozważań można stwierdzić, że chińska literatura miała być odwzorowaniem doskonałych kształtów/wzorów wytworzonych przez naturę. Za pomocą tych wzorów szeroko pojęte zaświaty komunikowały się z ludźmi i prawdopodobne jest, że ludzie, chcąc porozumiewać się z zaświatami, również robili to za pomocą wzorów (chińskich znaków). Pismo nie było zatem potrzebne jedynie do zapisania sekwencji dźwięków, jak ma to miejsce w przypadku języków posługujących się alfabetem. Jest zatem oczywiste, że będziemy dostrzegać pokłady tak zwanej „oralności” w tekstach zapisanych, ponieważ ewolucja nie zachodziła tu, jak zakładał Ong, w prostej linii od oralności do piśmienności. Dlatego ze względu na inne medium i funkcje zachodnie teorie są nieprzystawalne.

\section{UWAGI O LITERATURZE LUDOWEJ}

Na koniec warto jeszcze dla porządku na chwilę pochylić się nad chińską twórczością ludową, która rozumiana jest tu według zachodnich kryteriów (Podręczny stownik terminów literackich 130). Twórczość ludowa z pewnością należy do literatury oralnej, choć znów nie można by było zaliczyć jej do ongowskiej oralności pierwotnej. Zebrany w XX wieku i później materiał pochodzi wprawdzie bardzo często od na wpół piśmiennych mieszkańców odległych wiosek, ale trudno oczekiwać, że będą oni całkowicie odcięci od nowoczesnych mediów. Literatura ludowa była jednak obecna w kulturze 
chińskiej niemalże od początków piśmiennictwa. Władcy często odgórnie zarządzali zbieranie i spisywanie ludowych utworów. W pierwszej kolejności trzeba tu wymienić Księgę pieśni (詩經 shijing). W części feng (風) zawiera ona utwory podzielone na państwa, z których miały być rzekomo zebrane od tamtejszego ludu (Religa 78). Oczywiście zostały odpowiednio zredagowane przez nadwornych poetów/muzyków, z pewnością więc nie można mówić tu o jakimkolwiek oryginalnym materiale. Potrzeba jednak zbierania twórczości ludu utrzymała się i za dynastii Han powstał urząd do spraw muzyki, yuefu (樂府), który miał za zadanie właśnie zbieranie ludowych pieśni. Z czasem utwory, które „wychodziły” z biura, przekształciły się w gatunek literacki i za czasów Sześciu Dynastii yuefu było określeniem pewnego rodzaju poezji (Beecroft 28). Tutaj również można mieć wątpliwości, czy utwory te można zaliczyć do literatury ludowej. Beecroft wykazuje, że ostatecznie ludowe utwory mogły być jedynie inspiracją dla nowodworskich poetów (23-47).

Patrząc na biografie większości znamienitych poetów, można dostrzec pewien wzorzec: urzędnik albo zesłany za karę, albo wysłany ze względu na słabe wyniki egzaminów urzędniczych trafia na prowincję i tam blisko natury i ludu zaczyna tworzyć, inspirując się twórczością ludową.

Takie inspiracje nie dotyczyły tylko poetów, ale także prozaików; Gan Bao w przedmowie do Zebranych zapisków o zjawiskach nadprzyrodzonych (搜神記 soushenji) napisał, że swoje powiastki zbierał z różnych źródeł, również słuchając przeróżnych opowieści od ludzi zewsząd (Paśnik 27). Finnegan wspominała o źródłach jako ewentualnym czwartym kryterium oralności. Nie mamy pewności czy w przypadku Gan Bao same źródła były oralne, ale sposób przekazania ich Gan Bao już tak.

Jednym z pierwszych pasjonatów ludowych pieśni, który spisał je prawdopodobnie bez większych poprawek, był Feng Menglong (馮夢龍,1574-1646) (McLaren 160). W późniejszych okresach nie zaprzestano zbierania utworów ludowych. Można jeszcze wspomnieć o literaturze poszukiwania korzeni $\mathrm{z}$ lat 80. XX wieku, której twórcy jako młodzi ludzie, studenci (tzw. pokolenie zhiqingów 知識青年), często w czasie Rewolucji Kulturalnej byli zesłani w odległe rejony wiejskie do pracy i tam pierwszy raz mieli okazję zobaczyć kulturę ludową, bardzo często różnych narodowości zamieszkujących Chiny (zob. Kasarełł). W 2011 r. ukazała się The Columbia Anthology of Chinese Folk and Popular Literature pod redakcją Victora Maira i Marka Bendera. Jest to dotychczas najbogatszy zbiór utworów ludowych z terytorium Chin przetłumaczonych na język angielski. Obejmuje on 
zarówno pieśni liryczne, jak i obrzędowe, opowieści fabularne oraz utwory przeznaczone do wykonania przed publicznością.

Jak widać, tradycja zbierania utworów ludowych w Chinach jest bardzo stara. Jeśli jednak nawet założymy (bez żadnych podstaw i dowodów), że tekst, który się zachował, nie został w żaden sposób zmieniony, to w przypadku utworów ludowych, jak i innej twórczości oralnej posiadanie samego tekstu bez kontekstu jego wykonania jest tylko elementem całego utworu. Nawet współcześnie, gdy dostępny jest sprzęt do nagrywania audio i wideo, który jednie w niewielkim stopniu ingeruje w wykonanie, to kontekst wykonania również może być zniekształcony.

Nie ulega jednak wątpliwości, że z perspektywy omawianych tu zagadnień, a w szczególności „mocy słowa” literatura ludowa dostarcza ciekawych informacji. Za przykład mogą tu posłużyć lamenty przedślubne (哭嫁 歌 kujiage). Szczegółowo opisała to zjawisko Anne McLaren w książce Perfroming Grief. Bridal Laments in Rural China. Jest to zjawisko dość powszechnie występujące również w innych kulturach, gdyż jest związane $\mathrm{z}$ uniwersalnym $\mathrm{w}$ tym wypadku obrzędem przejścia. Można je zatem spotkać nie tylko u sąsiadów Chińczyków, np. u Mongołów, ale też i w pewnej odmianie w kulturze polskiej w postaci pieśni oczepinowych. Funkcje chińskich lamentów przedślubnych były wielorakie, również w pewnym sensie magiczne. McLaren twierdzi, że były żeńską ślubną wersją przedstawienia nuoxi (儺戲), które wywodziło się z egzorcystycznego rytuału o charakterze ochronnym (Perfroming Grief 105). Pieśń panny młodej chroniła zatem cały obrzęd zaślubin przed złymi duchami i zakłóceniami przez nie powodowanymi, które mogły wpłynąć negatywnie na cały okres trwania małżeństwa, nie tylko na samą ceremonię ślubną.

Wiara $\mathrm{w}$ moc śpiewanych pieśni obrzędowych jest obecna wszędzie, gdzie takie pieśni wykonywano. Można zastanawiać się, czy chodzi tu o sprawczą moc słowa samego w sobie, czy dźwięku lub dźwięku wyśpiewanego, czyli wydanego z ludzkiego gardła. Nie ulega jednak wątpliwości, że wszelkie pieśni wykonywane podczas rytuałów miały magiczną moc ochrony lub też kontaktu z zaświatami, a sam akt śpiewu można oczywiście zaliczyć do aktów o charakterze oralnym. 


\section{ZAKOŃCZENIE}

Jedną z wymienianych przez Onga cech oralności związaną ze sferą sacrum jest magiczna moc słowa, moc sprawcza. Ong pisze o tym następująco:

W większości religii słowo mówione łączy się niepodzielnie z życiem obrzędowym i religijnym. (...) Nawet jednak tradycja religijna opierająca się na tekście jest w stanie, na wiele sposobów, utrzymywać prymat oralności. Na przykład w chrześcijaństwie Biblię czyta się głośno podczas liturgii, uznając zawsze, że Bóg ,przemawia”, a nie pisze do istot ludzkich. (126)

W przypadku religii chińskich taką rolę słowa mówionego można dostrzec jedynie w buddyzmie, ale trzeba pamiętać, że buddyzm niósł w sobie całkowicie nową warstwę kulturową i tym samym dyskusyjne jest uwzględnianie go w tej analizie. W przytoczonych na początku legendach o powstaniu pisma oraz trygramów widać wyraźnie, że kosmos zdecydowanie pisze, a nie mówi, a człowiek, odwzorowując te znaki kosmosu, tworzy literaturę.

W taoistycznym tekście o początku świata, zatytułowanym Księga o początku kosmosu Najwyższego Laojuna (《太上老君開天經》 taishang laojun kaitianjing), datowanym na przełom III i IV wieku, można przeczytać, że kosmos wziął się z (mocy) owej księgi.

\section{太初之時, 老君從虛空而下, 為太初之師, 口吐《開天經》一部, 四十八萬 卷, 一卷有四十八萬字, 一字辟方一百里, 以教太初。(..) 太初得此老君開 天之經, 清濁已分, 清氣上昇為天, 濁氣下沉為地 (ctext.org/wiki.pl?if=gb\& chapter=903927).}

W czasie Wielkiego Zapoczątkowania, Laojun zstąpił z Próżni i Pustki i stał się Mistrzem Wielkiego Zapoczątkowania. Ze swych ust wydał Księgę o początku kosmosu w jednym tomie i 480 tysiącach znaków a każdy znak był wielki na 100 li i nauczał z niej o Wielkim Zapoczątkowaniu. (...) Gdy w Wielkimi Zapoczątkowaniu pojawiła się Księga Laojuna o początku kosmosu, czyste i zmącone już się rozdzieliły. Czysta pneuma uniosła się do góry i stała się Niebem, mętna pneuma opadła w dół i stała się ziemią ${ }^{8}$.

Kluczowym słowem jest zdecydowanie 吐 $t u$, które zostało przetłumaczone jako „wydał [z ust]”. Tu dosłownie znaczy wymiotować, wylewać, choć w późniejszych czasach było używane w przenośni jako „wypowiedzieć”.

\footnotetext{
${ }^{8}$ Tłum. Małgorzata Religa, niepublikowane materiały do wykładu „Filozofia i religie Chin”, prowadzonego na Uniwersytecie Warszawskim.
} 
Czasownik tu pojawia się także $\mathrm{w}$ innych tekstach czy komentarzach taoistycznych. Na przykład pojawia się w komentarzu Heshang Gonga (河上 公, ok. I wiek n.e.) do Daodejingu (《河上公老子注》), który jest tekstem znacznie wcześniejszym od przytaczanej wcześniej Księgi o początku kosmosu, może więc nieco rozjaśnić znaczenie, w jakim kontynuatorzy taoistycznej myśli mogli użyć tego czasownika. Heshang Gong, odnosząc się do pierwszych wersów o początku świata, pisze następująco: „,...) początek to źródło dao, wydycha/wydaje $(t u)$ z siebie $q i$ i rozprowadza transformacje ${ }^{9}$ ((...) 始者道本也, 吐气布化 $)^{10}$,. Tutaj przedmiotem $t u$ jest $q i$, które bywa tłumaczone jako oddech, pneuma, (życiowa) energia (Encyclopedia of Taoism 562), czyli coś znacznie subtelniejszego od księgi. Nawet jednak jeśli przyjmiemy, że Laojun wydał z ust księgę w postaci energii, tak jak dao wydało $z$ siebie stwórcze $q i$, to nadal przy ani jednej, ani drugiej czynności nie ma mowy o dźwięku ani tym bardziej o mowie.

Może obraz Laojuna wydającego z ust Księgę zostanie tu pozostawiony wyobraźni czytelnika, czytając jednak ów cytat dalej, już wyraźnie jest napisane, że to pojawienie się Księgi, a nie sprawcze słowo Laojuna spowodowało oddzielenie nieba i ziemi, a znaki, którymi zapisana była owa księga, też nie były byle jakie, bo liczyły aż sto $l i$, czyli 50 kilometrów!

Chiński kosmos nie mówi do człowieka:

子曰：「予欲無言。」子貢曰：「子如不言，則小子何述焉？」子曰:「天 何言哉？四時行焉，百物生焉，天何言哉？」

Mistrz powiedział: „Pragnę przestać mówić”. Zigong rzekł: „Mistrzu, jeśli przestaniesz mówić, to co my, uczniowie, będziemy przekazywać?”. Mistrz powiedział: „Czy niebo (tian 天) mówi? Cztery pory roku następują po sobie, wszystkie rzeczy powstają, ale czy niebo mówi?" (Analekta, thum. Katarzyna Pejda, 189)

Kontekst tego fragmentu jest oczywiście nieco inny, ale nadal przekaz jest jasny: niebo nie mówi, a wszystko się dzieje jak należy w swoim naturalnym porządku.

Jeśli chodzi zatem o sferę religijną i o zasięg działania, zdecydowanie to słowo pisane ma większą moc niż wypowiedziane, choć oczywiście istnieją również taoistyczne zaklęcia (Strickmann 89-103). Innym dowodem na magiczną moc znaku, choć może i w tym wypadku pisma, mogą być chińskie taoistyczne talizmany 符錄 fulu. Jak sama nazwa wskazuje, miały

\footnotetext{
${ }^{9}$ Tłum. Małgorzata Religa.

${ }^{10}$ ctext.org/wiki.pl?if=gb\&chapter=29\&remap=gb\#\%E4\%BD $\% 93 \% \mathrm{E} 9 \% 81 \% 93 \% \mathrm{E} 7 \% \mathrm{AC} \%$ AC\% E4\%B8\%80. Dostęp 27.03.2021.
} 


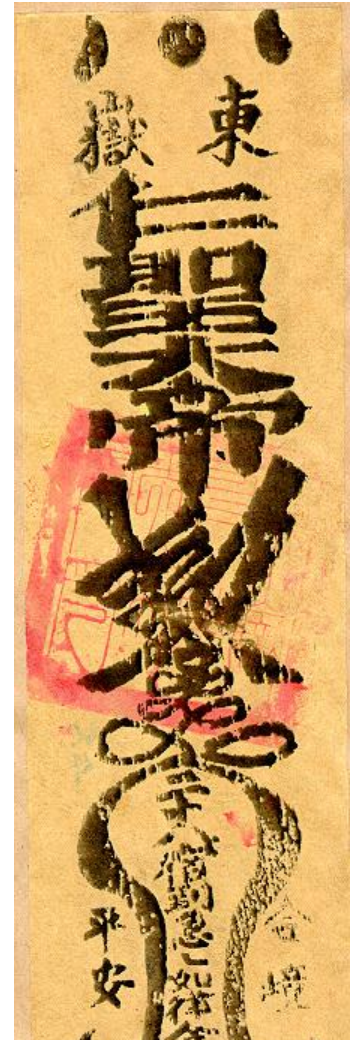

Ilustracja 3. Taoistyczny talizman.

Źródło : zh.wikipedia.org/ wiki/ E7\%AC\%A6\%E7\%B1 $\% 99 \# /$ media/File:TaoistChar m.JPG, dostęp 26.03.2021

związek z tzw. Rejestrami (錄 $l u$ ), które zawierały między innymi imiona wszystkich demonów, a zapisanie jego imienia razem $\mathrm{z}$ odpowiednim nakazem miało moc egzorcystyczną. Taki talizman był pisany przez kapłana, a następnie musiał zostać spożyty przez chorego. Na przykład po spaleniu popiół był mieszany z płynem i podawany do spożycia, co po wypędzeniu demona choroby miało moc uzdrawiającą. Natomiast w rodzinnej obrzędowości ludowej z przyczyn oczywistych to dźwięk, słowo śpiewane zdecydowanie wiodło prym. Czy zatem można powiedzieć, że Chiny to kultura znaku, nie dźwięku? Jest to pytanie, na które chyba nigdy nie będzie można udzielić jednoznacznej odpowiedzi, choć trzeba przyznać, że moc znaku w kulturze chińskiej jest jeśli nie większa, to przynajmniej równa mocy słowa mówionego.

Na przedstawionych przykładach widać wyraźnie, że w przypadku piśmiennictwa czy literatury chińskiej należy stosować metodologie, które nie będą postrzegać oralności i piśmienności binarnie oraz będą uwzględniać emiczne postrzeganie tekstu, a także jego funkcje i medium. W dalszych badaniach należy uwzględnić również badania nad językiem, także w ujęciu emicznym ${ }^{11}$.

\section{PODZIĘKOWANIA}

$\mathrm{Na}$ koniec chciałabym podziękować Małgorzacie Relidze i Marianowi Olechowi, koleżankom i kolegom, a także moim studentom za inspirujące rozmowy, bez których ten tekst by nie powstał.

\footnotetext{
${ }^{11}$ Częściowo ten temat został podjęty przez Chada Hansena - zob. zwłaszcza jego artykuł „Ideographs and Western Ideas”.
} 


\section{BIBLIOGRAFIA}

Analekta. Tłum. i oprac. Katarzyna Pejda. Wydawnictwa Uniwersytetu Warszawskiego, 2018.

Baidu. baike.baidu.com/pic/\%E6\%9B\%B0/9421784/0/78310a55b319ebc4b74584119e6fd8fc1e178 b82b8a8? fr=lemma\&ct=single\#aid=0\&pic $=78310 \mathrm{a} 55 \mathrm{~b} 319 \mathrm{ebc} 4 \mathrm{~b} 74584119 \mathrm{e} 6 \mathrm{fd} 8 \mathrm{fc} 1 \mathrm{e} 178 \mathrm{~b} 82 \mathrm{~b} 8$ a8. Dostęp 23.03.2021.

Baidu. baike.baidu.com/pic/\%E7\%A5\%9D/54167/0/9a504fc2d56285355d3f24ea9cef76c6a6ef6 $31 \mathrm{a}$ ?fr=lemma\&ct $=$ single\#aid $=0 \&$ pic $=9 \mathrm{a} 504 \mathrm{fc} 2 \mathrm{~d} 56285355 \mathrm{~d} 3 \mathrm{f} 24$ ea $9 \mathrm{cef} 76 \mathrm{c} 6 \mathrm{a} 6 \mathrm{ef} 631 \mathrm{a}$. Dostęp 23.03.2021.

Beecroft, Alexander. "Oral Formula and Intertextuality in the Chinese 'Folk' Tradition(Yuefu)". Early Medieval China, no. 15, 2009.

Birrell, Anne. The Classic of Mountains and Seas. London: Penguin Books, 1999.

Brokaw, Galen. "An Integrational Approach to Colonial Semiosis". The Routledge Hispanic Studies Companion to Colonial Latin America and Carribean (1492-1898), red. SanMiguel Martinez. Routledge, 2021.

Chang, K.C. Art, Myth and Ritual. The Path to Political Authority in Ancient China. Harvard University Press, 1983.

Chinesenotes. chinesenotes.com/wenxin/wenxin001.html. Dostęp 20.03.2021.

Chinese Text Project. ctext.org/guanzi/nei-ye. Dostęp: 25.03.2021.

Chinese Text Project. ctext.org/shan-hai-jing/nan-shan-jing. Dostęp 25.03.2021.

Chinese Text Project. ctext.org/wiki.pl?if=gb\&chapter=29\&remap=gb\#\%E4\%BD\%93\% E9\% 81\%93\%E7\%AC\%AC\%E4\%B8\%80. Dostęp 27.03.2021.

Chinese Text Project. ctext.org/wiki.pl?if=gb\&chapter=903927. Dostęp 25.03.2021.

Copp, Paul. "Anointing Phrases and Narrative Power: A Tang Buddhist Poetics of Incantation". History of Religions, vol. 52, no. 2, 2012.

Encyclopedia of Taoism, red. Fabrizio Pregadio, Routledge, 2008.

Estetyka chińska. Antologia, red. Adina Zemanek, Universitas, 2007.

Finnegan, Ruth. "How Oral Is Oral Literature". Bulletin of the School of Oriental and African Studies, vol. 37, no, 1, 1974.

Finnegan, Ruth, Oral Traditions and the Verbal arts. A Guide to research Practices. Routledge, 1992.

Finnegan, Ruth. Oral Literature in Africa. Open Book Publishers, 2012.

Gang Yue. Then Mouth that begs. Hunger, Cannibalism and the Politics of Eating in Modern China. Duke University Press, 1999.

Ge, Liangyan. Out of the Margins. The Rise of Chinese Vernacular Fiction. University of Hawai'i Press, 2001).

Goody, Jack. Literacy in Traditional Societies. Cambridge University Press, 1968.

Hansen, Chad. "Ideographs and Western Ideas". The Journal of Asian Studies, vol. 52, no, 2, 1993

Idema, Wilt, i Lloyd Haft. A Guide to Chinese Literature. The University of Michigan, Center for Chinese Studies, 1996).

The Interplay of the Oral and the Written in Chinese Popular Literature, red. Vibeke Børdahl i Margaret B. Wan, Niass Press, 2010. 
Kasarełło, Lidia. Totemy życia... Chińska literatura poszukiwania korzeni. Wydawnictwo Dialog, 2000.

Keightley, David M. Sources of Shang History. The Oracle-Bone Inscriptions of Brozne Age China. Universty of California Press, 1985.

LaFargue, Michael. The Tao of the Tao Te Ching. State University of New York Press, 1992.

Hsieh, Liu. The Literary Mind and the Carving of Dragons. Tłum. Vicent Yu-chung Shih. The Chinese Univeristy of Hong Kong Press, 2015, epub.

Liu, J.Y. James, Chinese Theories of Literature. The University of Chicago Press, 1975.

Lord, Albert B. The Singer of Tales. New York, Atheneum, 1971.

Luxun. 魯迅. 中國小說史略 [Zhongguo xiaoshuo shi lue]. 上海古籍出版社 [Shanghai guji chuban she], 2006.

Mair, Victor. T'ang Transformation Texts. A Study of the Buddhist Contribution to the Rise of Vernacular Fiction and Drama in China. Harvard University Press, 1989.

Mair, Victor, and Mark Bender. The Columbia Anthology of Chinese Folk and Popular Literature. Columbia University Press, 2011.

McLaren, Anne. Perfroming Grief. Bridal Laments in Rural China. University of Hawai'i Press, 2008.

NTI Reader. ntireader.org/taisho/t2003_06.html. Dostęp: 25.03.2021.

Ong, Walter J. Oralność i piśmienność. Słowo poddane technologii. Tłum. i red. naukowa Józef Japola. Wydawnictwa Uniwersytetu Warszawskiego, 2011.

Paśnik, Ewa, Duchy i czary chińskie czyli palimpsestowy charakter zebranych zapisków o zjawiskach nadprzyrodzonych. Wydawnictwa Uniwersytetu Warszawskiego, 2013.

The Platform Sutra of the Sixth Partiarch. Tłum. John Mc Rae. Numata Center for Buddhist Translation and Research, 2000.

Podręczny słownik terminów literackich, red. Janusz Sławiński, Wydawnictwo Open, 1994.

Qiu, Xigui. "The Early China Forum An Examination of Whether the Charges in Shang OracleBone Inscriptions are Questions." Early China, vol. 14, 1989.

Religa, Małgorzata. "Kanoniczne księgi Chin”. Wielkie księgi ludzkości, red. Anna Czajka, Wydawnictwo Uniwersytatu Kardynała Wyszyńskiego, 2013.

Roth, Harold. Inward Training (Nei-yeh) and the Foundations of Taoist Mysticism. Columbia University Press, 1999.

Shen, Pei. 沈培. 說古文字裏的“祝”及相關之字. 《簡帛》[Shuo guwenzi li de “zhu” jí xiāngguān zhī zì,,“jiăn bó”], t. 2, 上海古籍出版社, [Shanghai gují chuban she], 2007.

Słupski, Zbigniew. Wczesne piśmiennictwo chińskie. Wydawnictwo Agade, 2001.

Sørensen, Henrik H., "Spells and Magical Practices as Reflected in Early Chinese Buddhist Sources (c. 300-600 CE) and Their Implication for the Rise and Development of Esoteric Buddhism." Chinese and Tibetan Esoteric Buddhism, red. Yael Bentor i Meir Shahar, Brill, 2017.

Strickmann, Michel. Chinese Magical Medicine. Stanford University Press, 2002.

Takács, Dániel V. "Performing Eternally: Visible Signs of Oral Tradition in Ancient Egypt". The Art, the Oral and the Written Intertwined in African Cultures, red. Zuzanna Augustyniak i Hanna Rubinkowska-Anioł. Seria: The Artistic Traditions of Non-European Cultures, t. 6. Polish Institute of World Art \& Tako Publishing House, 2018.

Wang, Youru. Historical Dictionary of Chan Buddhism. Rowman \& Littlefield, 2017. 
Wéiji baike. 维基百科. zh.wikipedia.org/wiki/\%E7\%AC\%A6\%E7\%B1\%99\#/media/File: Taoist Charm.JPG. Dostęp 26.03.2021.

Ze, David. "Walter Ong's Paradigm and Chinese Literacy."_Canadian Journal of Comunication, www.holst.no/Ingar.Holst.Publishing.Co/docs/WalterOngsParadigmandChineseLiteracy. pdf. Dostęp 24.03.2021.

\section{INNY RODZAJ PIŚMIENNOŚCI. \\ O ASPEKTACH NIEBINARNOŚCI ORALNOŚCI I PIŚMIENNOŚCI W LITERATURZE CHIŃSKIEJ NA WYBRANYCH PRZYKŁADACH}

Streszczenie

Głównym zamierzeniem poniższego artykułu jest wykazanie, że nie jest naukowo poznawcze w przypadku chińskiej literatury stosowanie rozróżnienia na oralność i piśmienność według dychotomicznego modelu proponowanego na przykład przez Waltera Onga, jak również innych, bardziej „elastycznych” kulturowo narzędzi, które są jedynie częściowo przystawalne jak na przykład definicje Ruth Finnegan. Ze względu na powstające wątpliwości co do metodologicznej poprawności zastosowania narzędzi przyjętych na Zachodzie, została podjęta próba przedstawienia istoty chińskiej piśmienności oraz jej bardzo skomplikowanych relacji z oralnością. Zostały również zasygnalizowane problemy badawcze do dalszych rozważań nad tymi zagadnieniami, a egzemplifikacją do tych przemyśleń są wybrane utwory, które w tym kontekście, mimo dość obszernej bibliografii na temat twórczości oralnej w Chinach, nie zostały omówione lub zostały omówione niewystarczająco.

Słowa kluczowe: literatura chińska; oralność; piśmienność; Walter Ong; Ruth Finnegan. 